\title{
Nasal Bone 3 Dimentional Computer Tomography Guided Tailored Osteotomy of the Bony Deviated Nose
}

\author{
Joo-Wan Jo, Seok-Won Jeon, Joo-Geun Jung, and Min-Jung Kim \\ Department of Otorhinolaryngology, Wallace Memorial Baptist Hospital, Busan, Korea
}

\section{골성 사비 환자의 코성형술에 있어 비골 3차원 전산화단층촬영을 이용한 절골술}

조주완 · 전석원 · 정주근 · 김민정

왈레스 기념 침례병원 이비인후과

\author{
Received June 12, 2015 \\ Revised September 30, 2015 \\ Accepted October 8, 2015 \\ Address for correspondence \\ Min-Jung Kim, MD \\ Department of Otorhinolaryngology, \\ Wallace Memorial Baptist Hospital, \\ 200 Geumdan-ro, Geumjeong-gu, \\ Busan 46214, Korea \\ Tel $+82-51-580-1341$ \\ Fax $+82-51-514-2864$ \\ E-mail demi9300@nate.com
}

Background and Objectives Correction of deviated nose is considered one of the most difficult and serious surgical operations in rhinoplasty. The correction of bony deviation, in particular, requires osteotomy. Although there are individual differences in the shapes or features of bony deviations of each patient, the techniques of osteotomy are limited. Therefore, for proper correction of bony deviation, it is necessary to set up a precise pre-surgical plan. Subjects and Method We categorized 187 patients with bony deviated nose into 5 types based on the analysis of preoperative nasal bone 3D computer tomography, and studied surgical method for each type.

Results Of 187 patients, $92(49 \%)$ patients are categorized into type I, $62(36 \%)$ patients into type II, $12(6 \%)$ patients into type III, 2 (1\%) patients into type IVa, 7 (4\%) patients into type IVb and 7 (4\%) patients into type V. Only did eight patients (5\%) undergo revision surgery due to unsuccessful outcomes. Major complications like infection, abscess, arteriovenous fistula, epiphora, and saddle deformation did not occur at all.

Conclusion Preoperative planning under the analysis and categorization using 3D CT is considered helpful for the precise and individualized surgery in corrective rhinoplasty.

Korean J Otorhinolaryngol-Head Neck Surg 2016;59(1):19-27

Key Words 3D CT $\cdot$ Nose deformity · Osteotomy $\cdot$ Rhinoplasty.

\section{서 론}

외비의 비배부가 얼굴의 정중앙에서 벗어난 경우를 사비 (deviated, crooked, scoliotic nose)라 부른다. 사비는 크게 골 성 사비(bony deviation)와 연골성 사비(cartilaginous deviation)로 나눈다. 그중 골성 사비는 상위 $1 / 3$ 에 위치한 골부의 만곡을 지칭하고, 연골성 사비는 하위 $2 / 3$ 에 해당하는 부위의 만곡이다. ${ }^{1)}$ 이 중 골성 사비를 교정하기 위해 절골술을 시행 하여야 한다. 절골술은 침습적, 비가역적인 술식이다. 하지만, 골성 사비 환자의 비골 상태는 매우 다양하나 절골술은 한정 되어 있기 때문에 술 전 계획이 중요한데, 보이는 외형만을 근 거로 정확한 절골을 계획하기는 어려움이 있다. 특히 외상이
나 코성형수술 이후 재수술인 경우는 더욱 그렇다. 또한 동일 한 내측 절골이라도 시행부위가 골성 사비의 형태에 따라 다 를 수 있다. 그래서 여러 저자들이 사비 환자를 분류하고 그 분류에 따른 알고리즘을 만들어 사비를 교정하려는 시도가 있었다. ${ }^{1-4)}$ 그러나 다양한 비골의 상태를 분석하여 어떤 기준 으로 절골을 시행하는지에 대한 연구는 없었다.

이에 저자들은 골성 사비 환자에 수술 전 절골 계획에 있어 비골 3차원 전산화단층촬영(Nasal bone 3 dimensional computer tomography, Nasal bone 3D CT) 영상을 분석하여 골 성 사비 환자를 5 가지 type으로 분류하였으며, 이를 토대로 서로 다른 절골술을 시행하였다. 이에 좋은 결과를 얻었기에 비골 $3 \mathrm{D} \mathrm{CT}$ 를 통해 환자를 분류하는 방법과 수술 술기를 증 
례를 통해 보고하고자 한다.

\section{대상 및 방법}

\section{대 상}

2007년 3월부터 2015년 5월까지 사비로 외비성형술을 시행 한 270예의 환자 중 연골성사 비만 있는 환자를 제외하고 골 성 사비가 있는 187 예를 대상으로 절골술을 시행하였다. 수술 받은 모든 환자를 대상으로 술 후 3 개월에서 5년까지 추적관 찰을 하였다.

환자의 사비를 정확하게 평가하기 위하여 외비성형술을 시 행하기 전 모든 환자를 대상으로 사진촬영을 시행하였다. 사 진은 정면(frontal view), 양측 측면(lateral view), 양측 사면 (oblique view), 기저(basal view), 상면(chin on chest view)의 7장으로 구성하였다. 상면사진의 정중선(midline)과 눈썹-비 첨 미용선(brow-tip aesthetic line)을 이용하여 골성 사비를 평가했다. 정중선은 양측 미간중앙(glabella)에서 비공점의 중 앙, 인중, 턱끝을 잇는 선이다. 눈썹-비첨 미용선(brow-tip aesthetic line)은 양측 눈썹의 내측에서 시작하여 비근 부위를 지나 비배부, 비첨 한정점(tip defining point)으로 이어지는 자 연스러운 2 개의 곡선이다. 정중선과 눈썹-비첨 미용선이 틀어 져 있는 경우를 사비로 정의하였다.
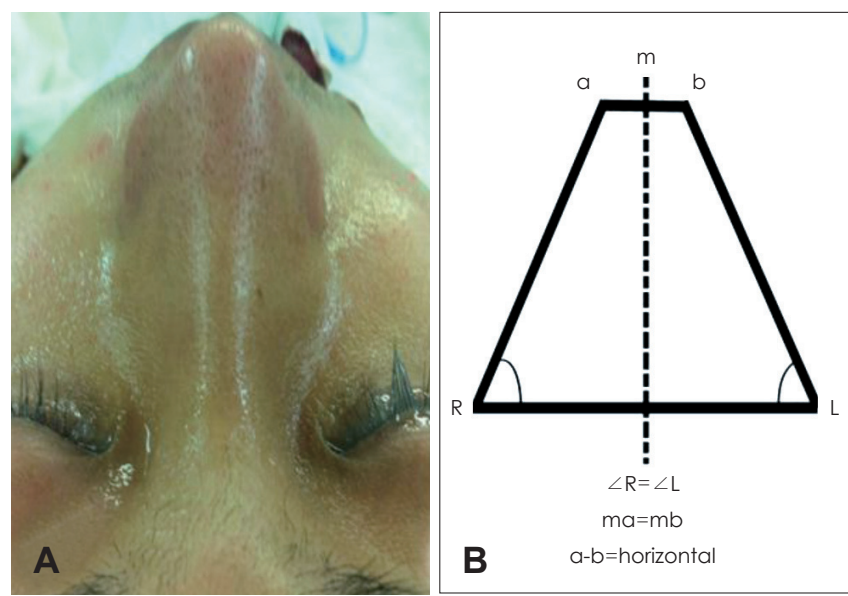

촬영된 사진과 거울을 보며 환자와 충분한 상담을 하여 수 술을 계획하였으며, 수술로 얻을 수 있는 목표를 정확하게 환 자에게 인지시키도록 하였다.

\section{비골 3D CT의 분석과 그에 따른 환자의 분류}

양측 눈썹-비첨 미용선을 평가하기 가장 좋은 시야는 상면 이다(Fig. 1A). 비골 3D CT의 입체 구성 화면을 술 전 촬영한 사진과 같은 시야로 비교 분석하였으며, 4 가지를 기준으로 분 석하였다. 첫째, 정중선과 양측 눈썹-비첨 미용선이 평행한지, 사비가 있다면 그 정도를 평가한다. 둘째, 정중선을 기준으로 양측 눈썹-비첨 미용선이 동일한 비폭(ma 길이 $=\mathrm{mb}$ 길이)을 이루는지, 좁거나 넓다면 얼마만큼인지 평가한다. 셋째, 눈썹비첨 미용선의 양측 비골 측벽이 동일한 기울기(각 $\mathrm{R}=$ 각 $\mathrm{L}$ )인 지 평가한다(Fig. 1B). 넷째, 양측 비골 측벽에 볼록함(convexity) 또는 오목함(concavity)이 있는지, 다섯째, 비골 결손 (defected nasal bone)이나 불규칙한 표면은 없는지 확인한다. 비골 $3 \mathrm{D}$ CT의 입체 구성 화면 중 상면이미지와 기저이미지를 주로 분석하였으나, 넷째와 다섯째 기준에 해당하는 것을 확 인하기 위해 CT의 축상면(axial view)을 재확인하였다(Fig. $1 \mathrm{C}$ and $\mathrm{D})$.

비골 3D CT을 이용하여 골성 사비 환자를 평가한 후, 모두 5 가지 type으로 환자를 분류하였다(Table 1); type I은 양측

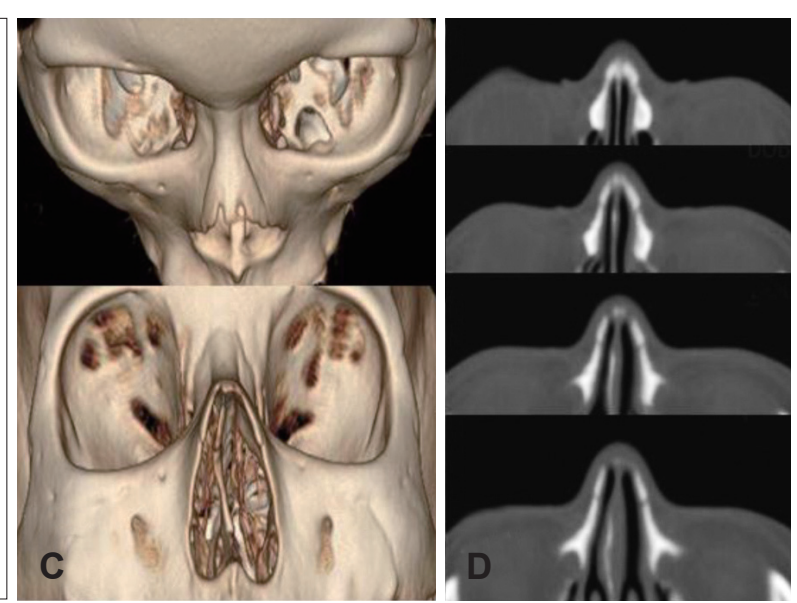

Fig. 1. The preoperative picture, schematic image and CT images of patient with normal nasal dorsum. Chin on chest view picture (A). Schematic image of bony pyramid (B). 3D reconstructed CT images (C). Axial view CT images (D).

Table 1. Classification of the bony deviated nose

\begin{tabular}{cl}
\hline Type & \multicolumn{1}{c}{ Description } \\
\hline I & Deviated bony pyramid to one side+equal both dorsal width \\
III & Deviated bony pyramid to one side+different both dorsal width+proturuded nasal dorsum \\
IV & Deviated bony pyramid to one side+tilted nasal dorsum \\
a & Not deviated bony pyramid+defected nasal bone \\
b & Deviated bony pyramid to one side+defected nasal bone \\
$V$ & Saddle nose
\end{tabular}


측벽의 기울기는 다르나 비배부의 수평부가 중앙선을 기준으 로 양측이 같은 경우(Fig. 2); type II는 양측 측벽의 기울기는 다르며 비배부가 편측은 좁아지고 반대측은 튀어나온 경우 (Fig. 3); type III는 양측 측벽의 기울기가 다르며 비배부에 편 평한 부분이 없는 경우다(Fig. 4). Type IV는 비골 결손으로 인 해 외형상 사비로 보이는 경우로 하였다. 세부적으로 type IVa 는 좌우 측벽의 기울기는 같고 비골 결손이 있는 경우며(Fig. 5), type IVb는 비골 결손이 있으면서 비골 측벽의 기울기가 다른 경우이다(Fig. 6). 마지막으로 type V는 안장코(saddle nose) 를 동반한 경우다(Fig. 7).

\section{수술 방법}

수술은 187예의 모든 환자들을 대상으로 전신마취하에 골 성 사비의 정확한 교정을 위하여 개방형 외비성형 접근법 (open rhinoplasty approach)으로 시행하였다.

Type I

Type I은 편측 비골 측벽의 기울기가 감소되었으나, 비배부
의 수평은 잘 유지되는 경우다(Fig. 2A). 중앙에서 수평의 좌 우측 길이는 같으나, 외상 등의 원인에 의해 편측 비골의 측벽 이 비배부 아래쪽으로 내려가 편측의 기울기가 감소한 경우이 다. 정면 사진에서 비골의 우측벽이 수평부의 비배부 밑으로 함몰되어 있다(Fig. 2B). 비골 3D CT에서 좌우측 비배부의 수 평은 잘 유지되나 우측 측벽의 기울기가 좌측에 비해 작아져 있다(Fig. 2D). 함몰되어 작아진 우측 측벽의 기울기(각 R)를 다시 크게 하기 위해서 그 부위에 절골하면 재함몰의 가능성 이 높다. 우측 비골의 함몰부위와 동일한 부위의 좌측 비골에 내외절골술을 시행하여 좌측 측벽의 기울기(각 L)를 작게하여 양측벽의 기울기를 대칭적으로 교정한다(Fig. 2E). 수술 후 촬영 한 정면사진에서 양측 눈썹-비첨 미용선이 대칭이다(Fig. 2C).

Type II

Type II는 양측 측벽의 기울기가 다르며, 비배부가 편평하나 정중선을 기준으로 편측은 좁아지고 반대측은 튀어나온 경우 다. 도식적인 이미지에서 우측 비골 측벽의 기울기(각 R)가 감 소되어 있으며, 정중선 $(\mathrm{m})$ 을 기준으로 우측의 비배부(ma 길
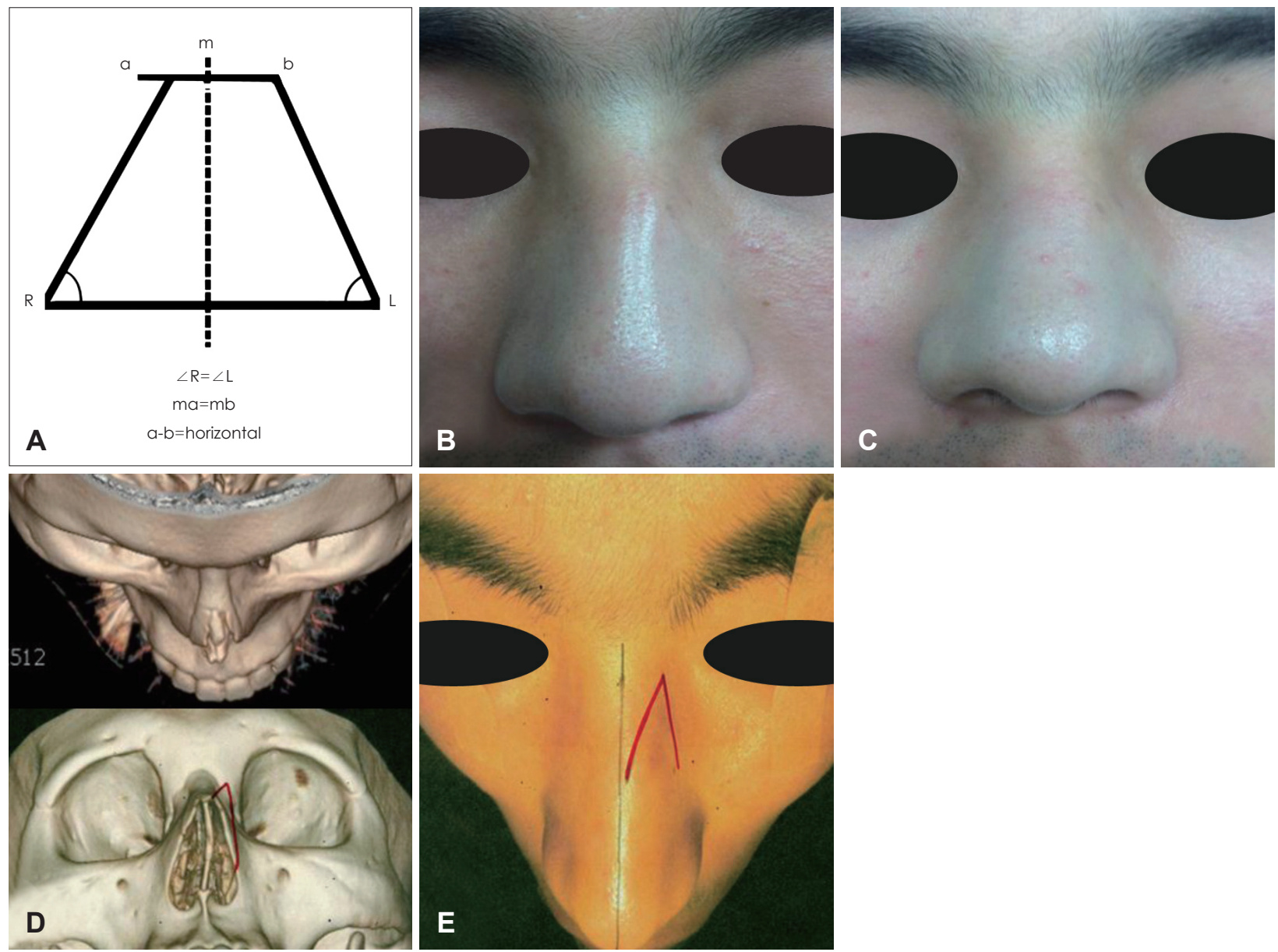

Fig. 2. The images for type I deviated nose. Schematic image of bony pyramid (A). Preoperative frontal view picture (B). Postoperative frontal view picture (C). 3D reconstructed CT images (D). Left medial and lateral osteotomies were planned (E). 

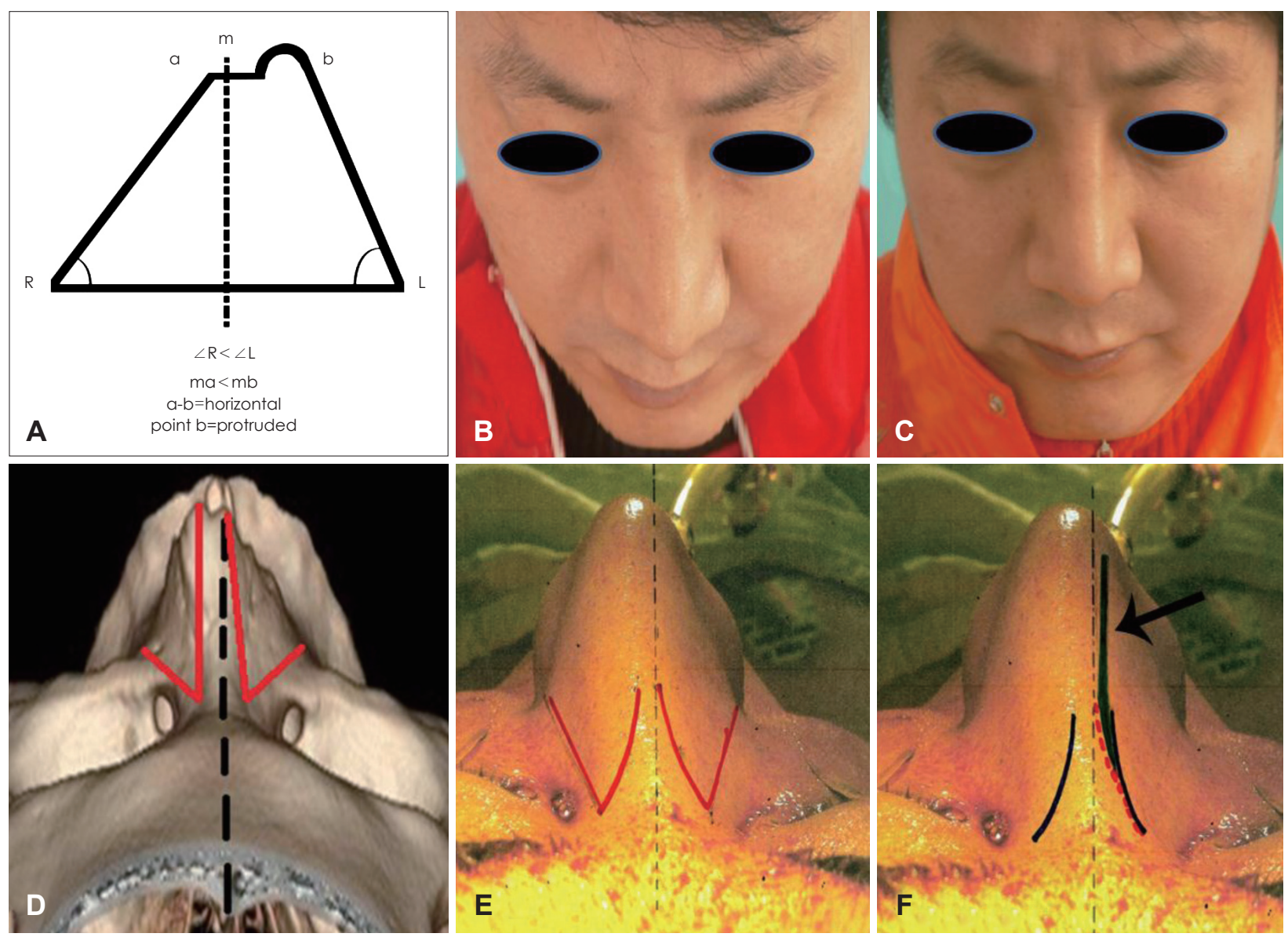

Fig. 3. The images for type II deviated nose. Schematic image of bony pyramid (A). Preoperative chin on chest view picture (B). Postoperative chin on chest view picture $(C)$. Both medial and lateral osteotomies were planned (D and $E)$. The spreader graft (arrow) was planned on right nasal dorsum $(F)$.

이)가 좁아지며, 좌측의 비배부(mb 길이)는 넓고 튀어나와 있 다(Fig. 3A).

상면사진에서 눈썹-비첨 미용선이 좌측으로 편위 되어 보 인다(Fig. $3 \mathrm{~B}$ ). 비골 3D CT의 상면 이미지에서 동일한 소견을 보인다(Fig. 3D). 따라서 좌측 비배부의 튀어나온 부위에서 내 측 절골을 시작하여 절골판을 만들어 골판을 내림으로써 좌 측으로 편위된 눈썹-비첨 미용선을 우측으로 옮기고 커진 기 울기(각 $\mathrm{L}$ )도 작게한다. 정중선에서 우측 눈썹-비첨 미용선에 이르는 수평 배부(ma 길이)가 좁아져 있어 이를 복원해야 한 다. 우측 측벽이 기울기 시작하는 부위에서 내측 절골을 시작 하여 골판을 만들고, 그 사이에 부족한 편측 비배부의 넓이만 큼 비중격 연골을 재단하여 펼침이식(spreader graft)을 함으 로써, 우측 수평의 비배부(ma 길이)를 넓게 하고 작아진 기울 기(각 R)를 크게 한다. 상기 예에서는 양측 비골 측면의 굴곡 이 없으므로 양측 모두 외측 절골을 비안면구(nasofacial groove)에서 시행한다(Fig. $3 \mathrm{E}$ ). 수술 후 촬영한 상면사진에서 환자의 양측 눈썹-비첨 미용선이 휘어짐 없이 대칭적으로 교 정됨을 확인할 수 있다(Fig. 3 C).

\section{Type III}

Type III는 양측 측벽의 기울기가 다르며 비배부에 편평한 부분이 없는 경우다. 비배부의 편평부가 없는 것이 특징으로, 절골로 교정해도 양측 내측 절골 사이의 비배부가 편평하지 못한 형태이다(Fig. 4A).

상면사진에서 눈썹-비첨 미용선이 왼쪽으로 편위되어 있으 며, 좌측 비배부가 튀어나왔다(Fig. 4B). 비골 3D CT의 상면이 미지에서 우측 눈썹-비첨 미용선은 무너져 있고 좌측 눈썹비첨 미용선은 좌측으로 튀어나와 있으며 비배부는 편평한 부위가 없다(Fig. 4D).

우측의 감소한 편측 측벽의 기울기(각 R)를 증가시키고 비 배부를 편평하게 하기 위해, 정중선 $(\mathrm{m})$ 근처에서 내측 절골을 시행했다. 이어서 우측 외측 절골술을 시행하였다. 내측 절골 시행부위에 늑연골 펼침이식(costal cartilage spreader graft) 을 하여 우측의 감소한 기울기를 크게 하고 비배부 수평부를 복원한다. 좌측은 튀어나온 부위에서 내측 절골술을 시행하 고 외측 절골술을 시행하여 기울기(각 L)를 낮춘다. 이 환자의 경우에는 좌측의 볼록한 측벽을 교정하기 위해 측벽의 골절선 

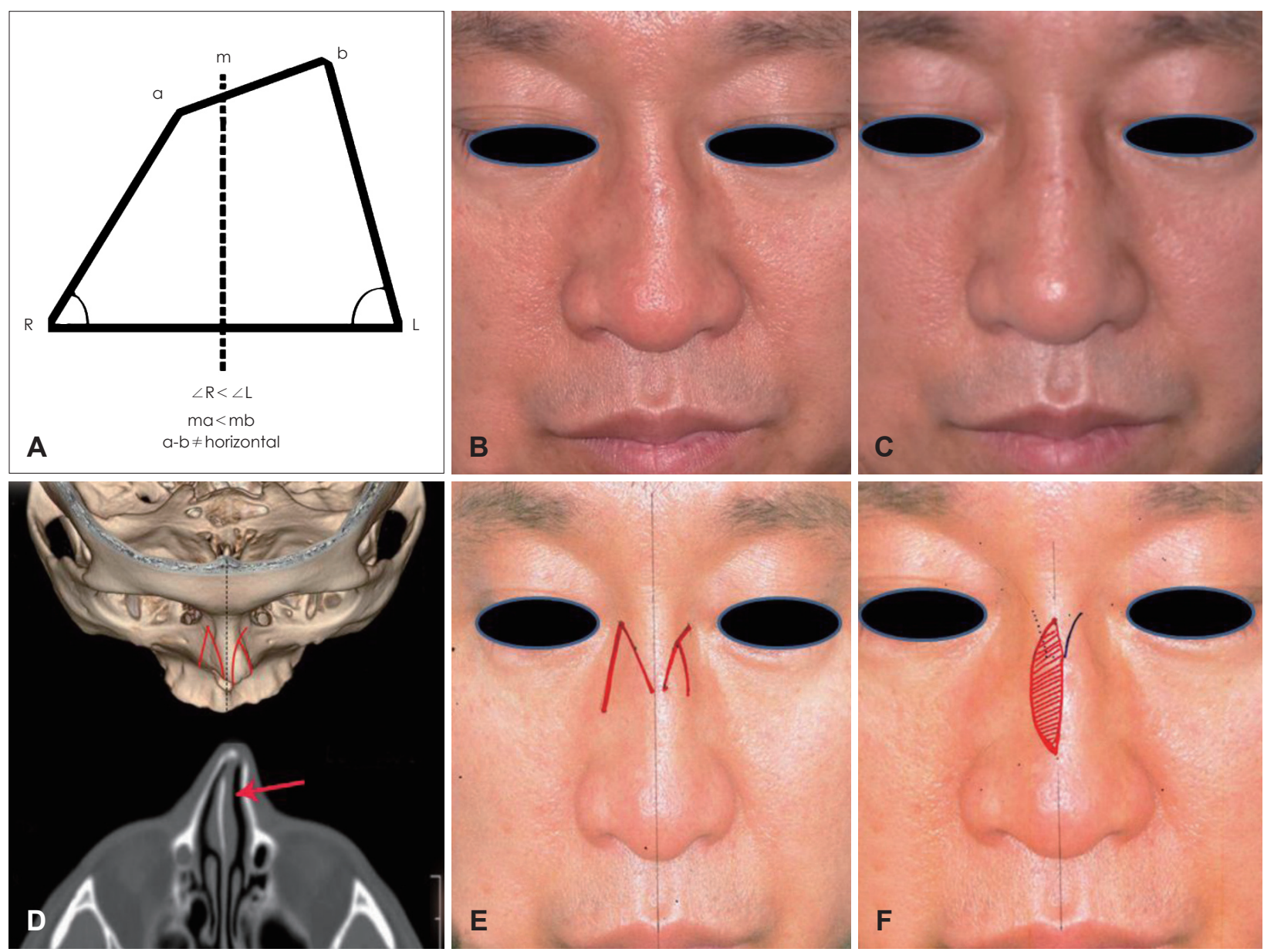

Fig. 4. The images for type III deviated nose. Schematic image of bony pyramid (A). Preoperative frontal view picture (B). Postoperative frontal view picture (C). Right medial and lateral osteotomies, left medial and intermediate (red arrow) osteotomies were planned (D and $E$ ). The camouflage graft (red area) was planned on right nasal dorsum (F).

이 있는 부위에 중간 절골술을 시행하였다(Fig. 4E). Type III 의 경우는 절골을 시행하여도 비배부가 정확히 편평해지지 않 는다. 따라서 편평하지 못한 비배부에 드릴링이나 위장술이 필 요하다. 본 예에서, 기울어진 좌측 비배부에 드릴을 이용하여 (burring with drill) 수평을 맞추었다. 마지막으로 수평폭과 기울기를 확인한 후 미흡한 부분이 있을 시 위장술(camouflage graft)을 비배부에 시행하였다(Fig. 4F). 수술 후 양측 눈 썹-비첨 미용선이 휘어짐 없이 대칭이며 비폭이 넓어진 것을 볼 수 있다(Fig. 4C).

\section{Type IV}

Type IV는 외상 또는 이전 수술로 인한 비골 결손이 있는 경우다. 이를 양측 측벽의 기울기에 따라 IVa와 IVb로 세분화 하였다.

Type IVa는 양측 측벽의 기울기는 같으나 비골 결손이 있 는 경우다(Fig. $5 \mathrm{~A}$ ). 상면사진에서 비골 결손으로 인해 우측의 눈썹-비첨 미용선이 무너지고 휘어 보인다(Fig. 5B). 비골 3D
CT에서 우측 비배부가 낮아보이는 원인이 비골 만곡이 아니 라 우측 비골의 결손임을 알 수 있다(Fig. 5D and E). 양측 측 벽의 기울기가 동일하나 골 결손에 의해 휘어 보이는 것으로, 절골을 하지 않고 교정한다. 우측 비골의 결손부위에 Expanded polytetraflouroethylene(e-PTFE, Goretex ${ }^{\circledR}$, Surgiform ${ }^{\circledR}$; Surgical Technology Laboratories, Columbia, OH, USA)을 디자인하여 위장술을 시행함으로써 결손을 교정한다(Fig. $5 \mathrm{~F})$. 수술 후 촬영한 상면사진에서 양측 눈썹-비첨 미용선이 대칭되게 교정되어 있다(Fig. 5C).

Type IVb는 양측 골편의 기울기가 다르며 비골 결손이 동 반된 경우다(Fig. $6 \mathrm{~A}$ ). 이 때는 절골이 필요하다. 정면사진에 서 좌측 눈썹-비첨 미용선이 좌측으로 편위되어 있다(Fig. 6B). 비골 $3 \mathrm{D} \mathrm{CT}$ 에서 이전의 우측 비골이 골절, 함몰되어 기 울기(각 R)가 감소되고, 좌측 측벽의 기울기(각 $\mathrm{L}$ )는 증가되어 있으며, 이전의 코성형수술로 인해 좌측 비골의 결손이 있다 (Fig. 6D). 좌측 내측 절골은 비골 결손이 끝나는 부위부터 시 행하고 외측 절골술을 시행하여 커진 좌측 측벽의 기울기(각 

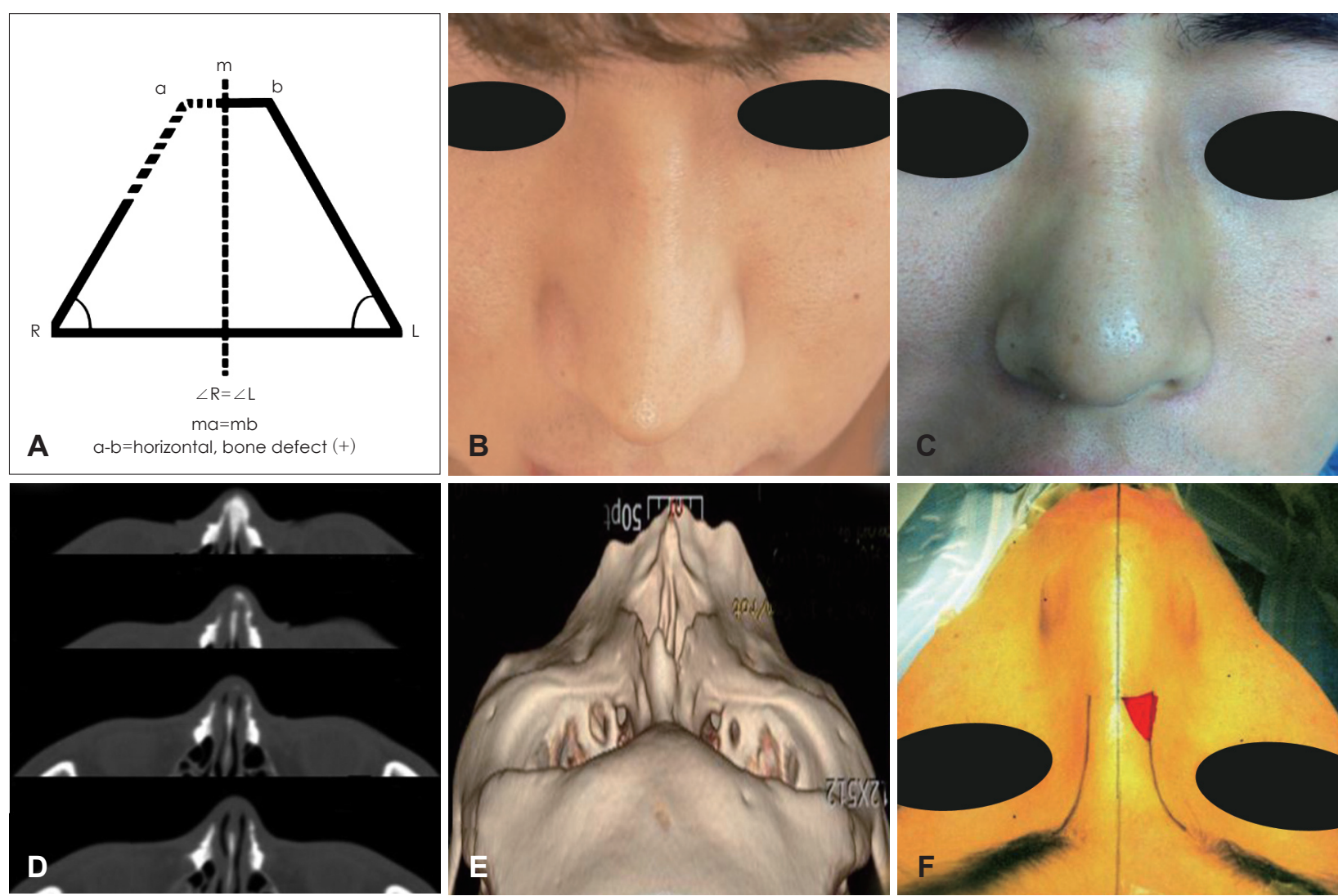

Fig. 5. The images for type IVa deviated nose. Schematic image of bony pyramid (A). Preoperative chin on chest view picture (B). Postoperative chin on chest view picture (C). Axial view CT images (D). 3D reconstructed CT image (E). The camouflage graft with Surgiform $^{\circledR}$ sheet (red area) was planned $(F)$.

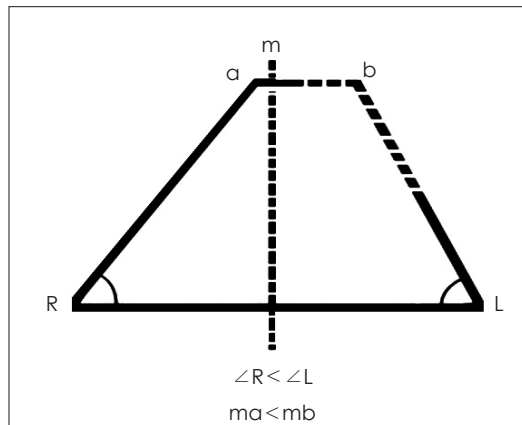

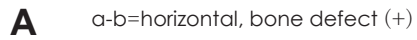

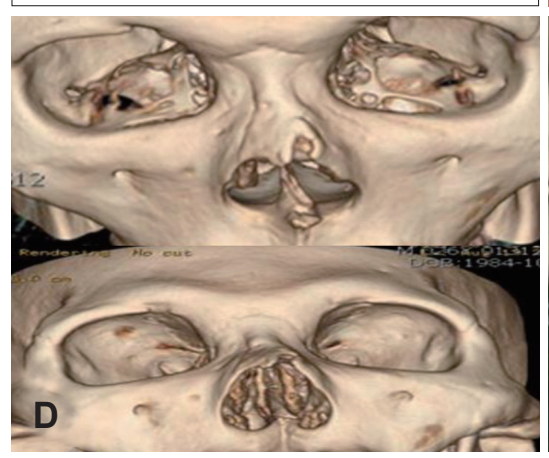

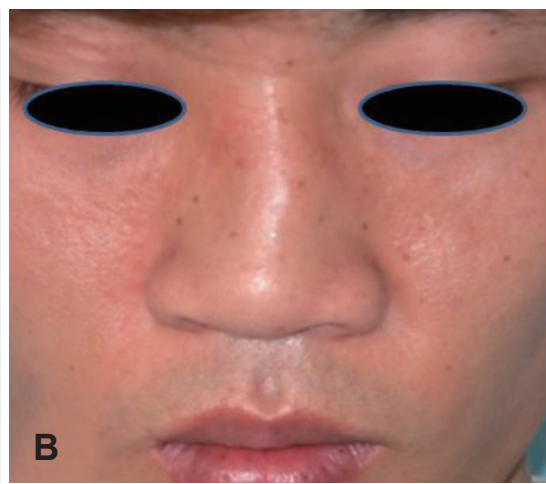
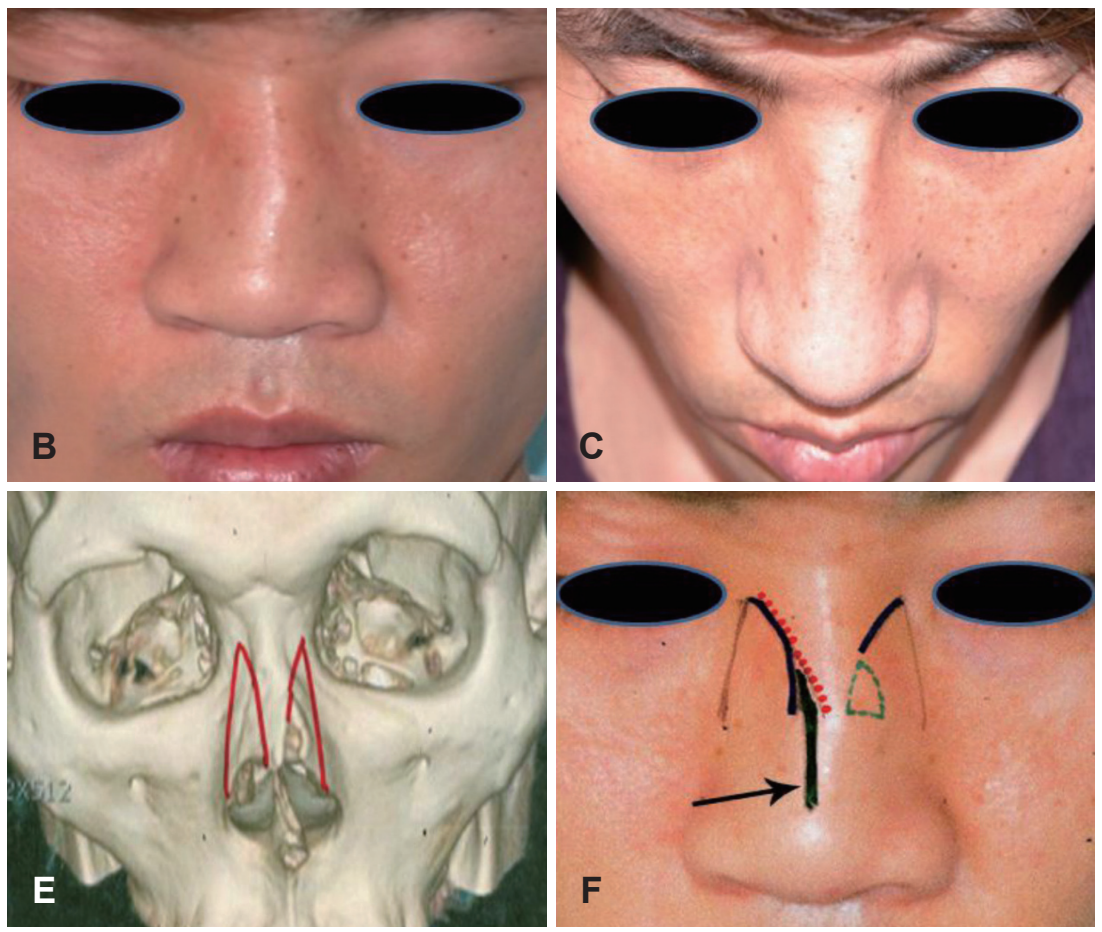

Fig. 6. The images for type IVb deviated nose. Schematic image of bony pyramid (A). Preoperative frontal view picture (B). Postoperative chin on chest view picture $(C)$. 3D reconstructed CT images (D). Both medial and lateral osteotomies was planned (E). Spreader graft (arrow) and camouflage graft (green line) were planned $(F)$. 
$\mathrm{L})$ 를 작게한다. 우측은 내외 절골술을 시행하는데 이때 내측 절골술은 정중선에서 시행한다. 우측 내측 절골부위에 늑연 골 펼침이식을 시행하여 우측 비배부의 수평부를 복원하고 기울기(각 R)를 증가시킨다(Fig. 6E). 결손부위에 Surgiform ${ }^{\circledR}$ (Surgical Technology Laboratories)을 이용한 위장술을 시행 후 융비술(augmentation)을 하였다(Fig. 6F). 수술 후 촬영한 상면사진에서 좌측 눈썹-비첨 미용선은 모두 평행하게 관찰 되며 비골의 돌출부위도 교정된 양상을 보인다(Fig. 6C).

Type V

Type V는 외상 또는 이전의 코 수술로 인해 안장코가 발생 한 경우다(Fig. 7A). 정면사진에서 양측 눈썹-비첨 미용선이 우측으로 편위되어 있으며, 좌측 비골은 함몰되어 있다(Fig. 7B). 측면사진에서는 심한 안장코를 보인다(Fig. 7C). 비골 3D CT에서 좌측 비배부에서 마룻돌 영역(keystone area)을 포함 한 비배부 전체의 함몰을 관찰할 수 있다(Fig. 7D). 안장코를 수술 시, 복잡한 절골술을 시행하면 안장코의 마룻돌 영역을 더 약화시킬 수 있다. 또한 높은 추가적 융비술이 필요한 경우
가 대부분이다. 따라서 우측 비공점의 돌출부위를 드릴을 이 용하여 좌우측 수평을 맞춘 후, 융비술을 시행하여 안장코를 교정하는 것이 전략적으로 유리하다. 수술 후 촬영한 정면, 측 면 사진에서 안장코와 사비가 교정되어 있는 것을 관찰할 수 있다(Fig. 7E and F). 그러나 좌우 비골 측벽의 기울기가 심하 게 다른 경우 절골을 시행할 수 있으나 가능한 보전적으로 시 행한다.

\section{결 과}

전체 187명 중 type I이 92명(49\%)으로 가장 많다. Type II 가 67명(36\%)으로 뒤를 이었으며, type III, IVa, IVb, V가 각 각 12명(6\%), 2명(1\%), 7명(4\%), 7명(4\%)이었다.

수술 후 결과에 대한 평가로 술 전 사진과 술 후 사진을 비 교하였다. 재수술(revision rhinoplasty)이 필요할 정도로 골성 사비가 제대로 교정되지 않는 경우(unsuccessful outcomes)는 type I에서 2예, type II에서 4예, type III에서 2예가 있었다 (Table 2).
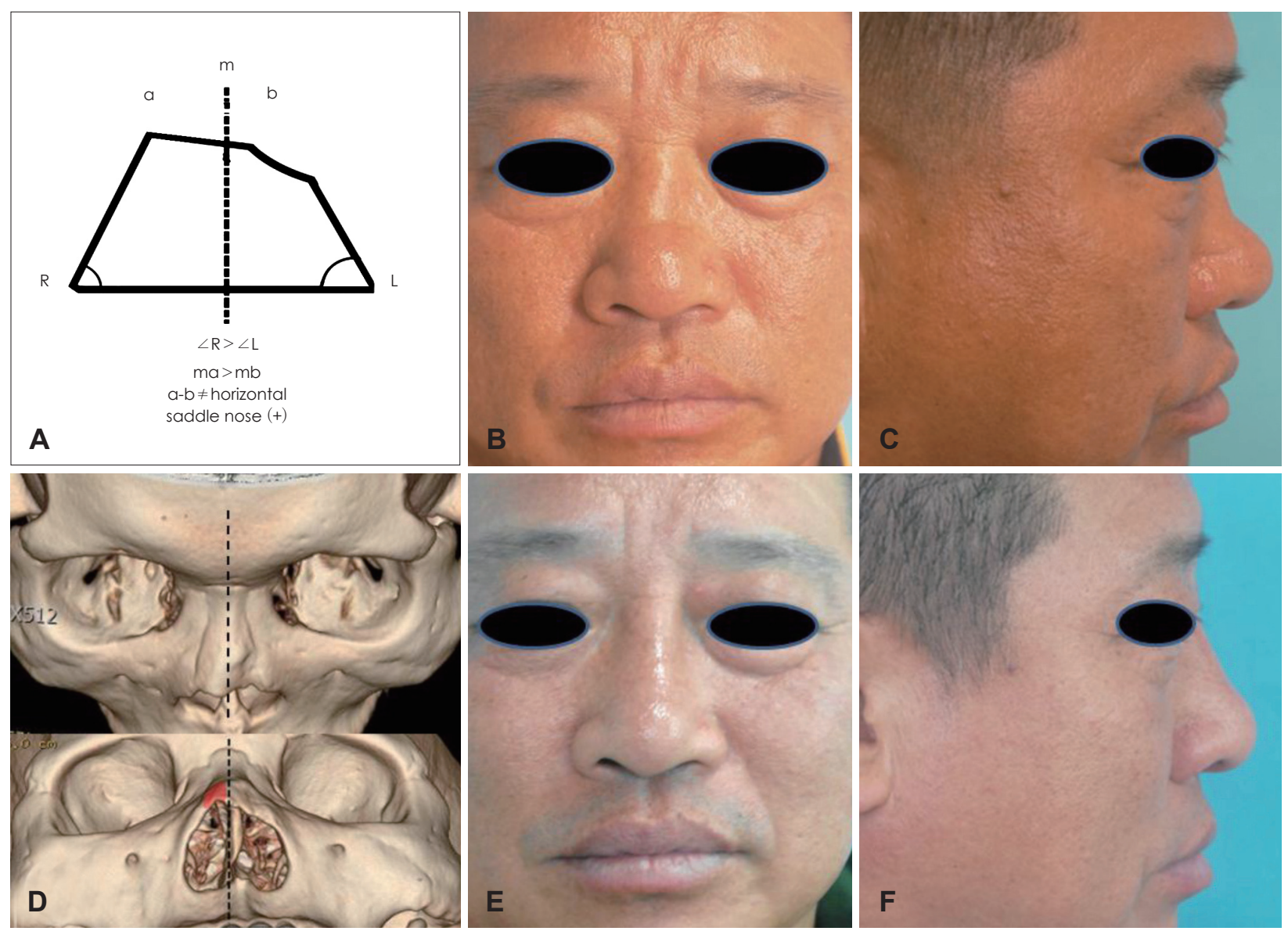

Fig. 7. The images for type $V$ deviated nose. Schematic image of bony pyramid (A). Preoperative frontal and lateral view pictures (B and C). 3D reconstructed images show the burring area that was planned on right nasal dorsum (red area) (D). Postoperative frontal and lateral view pictures ( $\mathrm{E}$ and $\mathrm{F})$. 
Table 2. Postoperative outcomes after nasal bone 3D-CT guided tailored osteotomy of the bony deviated nose $(n=187)$

\begin{tabular}{ccc}
$\begin{array}{c}\text { Classification } \\
\text { type }\end{array}$ & No. (\%) & $\begin{array}{c}\text { Unsuccessful } \\
\text { outcomes, no. (\%) }\end{array}$ \\
\hline I & $92(49)$ & $2(2)$ \\
II & $67(36)$ & $4(6)$ \\
III & $12(6)$ & $2(17)$ \\
IVa & $2(1)$ & $0(0)$ \\
IVb & $7(4)$ & $0(0)$ \\
V & $7(4)$ & $0(0)$ \\
\hline
\end{tabular}

187예 환자 모두에서 수술 후 감염, 농양, 육아종, 동정맥루, 유루증, 비강의 축소, 불안정한 비골부, 후각감소 등의 심각한 합병증은 나타나지 않았다. 하지만 경한 출혈, 술 후 부종, 반 상출혈 등의 합병증은 절골로 인해 자주 발생하였으나, 수술 후 수일 내로 회복되는 양상을 보였다.

\section{고 찰}

한국인에서 골성 사비의 비율은 전체 사비 환자 중에 약 $63 \%$ 로 보고된다. ${ }^{4}$ 본 연구에서도 골성 사비 환자의 비율이 약 $69 \%$ 였다. 즉, 사비 환자의 약 2/3에서 골성 사비를 동반하여 절골을 필요로 한다. 절골술은 비가역적 술식이며 심각한 합 병증을 유발할 수 있어 신중하게 시행을 결정해야 한다. ${ }^{5}$ 특 히, 동양인의 비골은 서양인에 비해 작고 두꺼워서, 다양한 절 골술을 시행하여도 각각의 시술에 대한 정확한 효과를 받지 못 하는 경우가 있으며, 분쇄골절(comminuted fracture)이 발 생할 수도 있어 절골술을 시행할 때 유의해야 한다. ${ }^{6}$ 또한, 외 비외상의 과거력이 있거나 예전에 코성형술을 받은 환자에 있 어서 비골의 상태는 개인 차이가 심하여, 보이는 외형만으로 절골 필요성 유무나 절골의 방법 등을 수술 전에 계획하는 데 어려움이 있다. 이러한 여러 가지 이유로 인해 절골술을 시행 하였으나 교정이 정확하게 되지 않는 비율이 보고마다 차이가 있지만 약 20 40\%로 보고된다. ${ }^{7)}$ 따라서, 골성 사비를 교정하 기 위해 환자에 대한 정확한 술 전 평가와 계획, 절골에 대한 올바른 지식을 숙지하는 것이 필수적이다.

사비 교정을 위한 접근 방법은 비내접근법과 비외접근법 으로 나눌 수 있고, 비외접근법(open rhinoplasty approach)이 수술 중 시야가 더 좋고 사비 교정을 위한 다양한 술식을 시행 할 수 있다. ${ }^{4}$

절골술을 시행하는 목적은 크게 비골 피라미드(bony pyramid)의 비대칭을 교정하거나, 비혹제거술(nasal hump resection)로 인한 열린지붕변형(open roof deformity)을 교정하거 나, 비골 피라미드의 볼록함/오목함을 교정하기 위해 시행한 다. ${ }^{8)}$ 절골술의 종류에는 크게 내측 절골술(medial osteoto- my), 외측 절골술(lateral osteotomy), 중간 절골술(intermediate osteotomy) 등이 있다. ${ }^{2,3)}$ 사비를 정확히 교정하기 위해 선 외측 절골술과 내측 절골술이 연결되어 비골 피라미드가 자유롭게 움직일 수 있어야 한다. 비골이 심하게 볼록하거나 오목할 경우에는 중간 절골술을 시행한다. ${ }^{3)}$ 그리고 내외 절골 술을 시행한 후에도 비근부의 변형이 있다면 $2 \mathrm{~mm}$ 의 작은 절 골도를 이용하여 경피적 비근부 절골술(percutaneous root osteotomy)을 시행하여 교정할 수도 있다. ${ }^{9)}$

다양한 사비를 분류하고 그 분류에 따라 알고리즘을 만들 어 치료하려는 연구는 기존부터 계속 있어 왔다. Boccieri와 Pascali $^{1)}$ 와 Porter와 Toriumi ${ }^{2}$ 는 사비의 부위에 따라 상부 $1 / 3$ (골성 사비), 하부2/3(연골성 사비)로 분류하였다. Rohrich 등 ${ }^{3)}$ 은 외비의 모양과 비중격의 모양을 참고하여 미부 중격 편 위(caudal septal deviation), 오목한 비배부 변형(concave dorsal deformity), 오목/볼록한 비배부 변형(concave/convex dorsal deformity)의 세 가지 기본 type으로 분류하였다. 하지 만, 이들은 사비를 외형에 따라 분류하여, 비골의 내부구조를 정확히 반영하지 못해 수술계획을 세우는 데 부족함이 있다. 이후, Jang 등 ${ }^{4)}$ 은 비골 피라미드와 연골성 비천장(cartilageous vault)의 모양을 보다 자세하게 5가지로 분류하였다. 이 는 정중선을 참고하여 분류하였다는 점에서 본 연구의 분류법 과 유사하나, 다양한 비골의 상태를 분석하여 어떤 기준으로 절골을 시행하는지에 대한 정보를 줄 수 있는 더 자세한 분류 법이 요구된다.

이에 저자들은 비골 $3 \mathrm{D} \mathrm{CT}$ 를 통해 골성 사비를 분류하여 절골의 필요성의 유무, 절골 방법과 위치, 추가적인 수술 방법 을 계획하였다. 정중선을 기준점으로 골성 사비 환자의 절골 을 계획하는 것이 중요하다. 하지만 기본적인 CT의 축상면 이 미지에서 정중선과 눈썹-비첨 미용선을 찾을 수는 있으나 각 이미지 간의 수직적인 상호관계를 파악하기 힘들다. 따라서, 전체적으로 한눈에 볼 수 있는 비골 $3 \mathrm{D} \mathrm{CT}$ 를 이용하여 정중 선과 눈썹-비첨 미용선을 찾고 수술 계획을 세우는 것이 유리 하다. 비골 측벽의 굴곡, 기울기의 차이와 골 결손은 축상면 이미지에서 더 정확하게 평가할 수 있다. 따라서 비골 3D CT 를 통해 전반적인 비골의 형태를 분석하고, 축상면 이미지로 재확인하는 것이 좋다.

비골 3D CT를 분석함에 있어 사비가 없는 코의 기준은 다 음과 같다. 첫째, 비근부의 중앙, 비공점의 중앙과 인중의 중앙 이 수직선상에 있어야 하며, 둘째, 정중선을 기준으로 양측 비 배부의 폭이 동일해야 한다. 셋째, 눈썹-비첨 미용선 양측의 비골의 기울기가 동일해야 하며, 넷째, 좌우측 비골 측벽의 곡 면(convexity, concavity) 차이가 없어야 한다. 다섯째, 비골에 결손부위가 없어야 한다. 
Table 3. Correction principle according to classification

\begin{tabular}{cl}
\hline Type & \multicolumn{1}{c}{ Description } \\
\hline I & Unilateral medial \& lateral osteotomies in the deviated side \\
III & Bilateral medial \& lateral osteotomies +spreader graft \\
IVa & Bilateral medial \& lateral osteotomies+spreader graft+burring with drill \pm camouflage graft \\
IVb & Camouflage graft \\
V & Bilateral medial \& lateral osteotomies+camouflage graft \\
\hline
\end{tabular}

비골 3D CT를 기준으로 수술을 계획함에 있어 다음과 같 은 기본원칙을 따른다.

1) 앞에서 언급한 정중선을 제일 먼저 찾아야 한다.

2) 중앙지점을 찾은 후에 좌우 측의 비배부가 좁아졌는지 혹은 넓어졌는지를 분석하여 내측 절골 시작 지점을 정한다. 비배부가 넓어져 있다면 남는 부분을 시작점으로, 일반적으로 가장 튀어나와 있는 부분에서 내측 절골을 시작한다. 그러면 튀어나온 부위는 함몰되어 비폭이 좁아지고 각은 작아진다. 비배부가 감소되어 있는 쪽은 연골 펼침이식을 하여 비배부를 넓히고 측벽의 기울기도 크게 한다. Type II가 이에 해당하고 사비를 교정하는 가장 기본적인 술식이다. Type III와 같이 비 배부의 수평부가 없이 양측으로 모두 기울어져 있는 경우는 type II의 더욱 심한 형태다. 이 경우에는 type II와 동일한 방 법으로 양측 비골 측벽의 기울기를 맞추고, 양측 내측 절골 사이 비배부에 드릴링, 위장술 또는 융비술을 추가로 시행하 여 편평하게 교정한다.

3) type I와 같이 양측의 비배부의 길이가 같고 편측 측벽의 기울기만 작아진 경우에는 각이 큰 측(일반적으로 외상이 없 었던 측)에만 내외 절골술을 시행하여 각을 작게 함으로써 양 측 각을 대칭적으로 맞춘다. 일반적으로 튀어나와 보이는 측 에 내외 절골술을 시행하면 된다.

4) type IV와 같이 골 결손이 있는 경우, 양측의 비골 측벽 의 기울기가 동일한 경우(type IVa)는 골 결손부위에 위장술 로 교정하지만, 비골 측벽의 기울기가 다른 경우(type IVb)에 는 type II와 동일한 방식으로 교정한다.

5) 양측 비골 측벽에 곡면이 있는 경우, 볼록한 부위는 중간 절골술로 교정하며, 오목한 부위는 절골보다는 위장술을 시행 한다. 중간절골술을 시행하는 위치는 CT를 통해 결정한다.

6) 안장코가 있는 경우는 마룻돌 영역이 약한 것으로 간주 하여 절골술보다는 드릴링과 융비술로 사비를 교정하는 것을
원칙으로 한다. 특히, 안장코가 있으면서 비배부가 많이 낮은 경우에는 융비술을 높게 시행할 수 있으며 비배부 수평부의 남아 있는 불규칙성도 융비술에 의해 가려질 수 있다. 따라서, 측벽의 기울기에 더 신경을 써야 하고, 융비술에 사용할 재료 가 닿는 비골부위, 특히 비공점에 드릴링을 시행하여 바닥이 수평이 되게 한다. 융비술의 재료는 실리콘이나 단단한 $\mathrm{e}^{-}$ $\mathrm{PTFE}$, 자가 늑연골 등 모두 사용 가능하나, 실리콘과 같이 재료가 단단할수록 불규칙한 부분을 가리는 데 더 유용하다. 그러나 융비술의 재료가 단단할수록, 이식물이 정확하게 들어 가지 않거나 비배부가 수평이 되게 드릴링을 하지 않을 경우 에는 이식물의 이동이나 장액종(seroma)의 발생이 더 빈번할 수 있어 장단점을 고려하여 재료를 선택해야 한다.

이상을 요약하면 Table 3과 같다.

\section{REFERENCES}

1) Boccieri A, Pascali M. Septal crossbar graft for the correction of the crooked nose. Plast Reconstr Surg 2003;111(2):629-38.

2) Porter JP, Toriumi DM. Surgical techniques for management of the crooked nose. Aesthetic Plast Surg 2002;26 Suppl 1:S18.

3) Rohrich RJ, Gunter JP, Deuber MA, Adams WP Jr. The deviated nose: optimizing results using a simplified classification and algorithmic approach. Plast Reconstr Surg 2002;110(6):1509-23; discussion 1524-5.

4) Jang YJ, Wang JH, Lee BJ. Classification of the deviated nose and its treatment. Arch Otolaryngol Head Neck Surg 2008;134(3):311-5.

5) Goldfarb M, Gallups JM, Gerwin JM. Perforating osteotomies in rhinoplasty. Arch Otolaryngol Head Neck Surg 1993;119(6):624-7.

6) Jung YG. Tailored correction of deviated nose. Korean J OtorhinolaryngolHead Neck Surg 2013;56(11):684-91.

7) Cho GS, Jang YJ. Deviated nose correction: different outcomes according to the deviation type. Laryngoscope 2013;123(5):1136-42.

8) Ghanaatpisheh M, Sajjadian A, Daniel RK. Superior rhinoplasty outcomes with precise nasal osteotomy: an individualized approach for maintaining function and achieving aesthetic goals. Aesthet Surg J 2015;35(1):28-39.

9) Jang YJ, Wang JH, Sinha V, Lee BJ. Percutaneous root osteotomy for correction of the deviated nose. Am J Rhinol 2007;21(4):515-9. 